DOI $10.14746 / \mathrm{ssp} .2021 .3 .1$

\title{
Kseniia Denysenko
}

Taras Shevchenko National University of Kyiv, Ukraine

ORCID ID: 0000-0003-1032-1281

Olena Kovtun

Taras Shevchenko National University of Kyiv, Ukraine

ORCID ID: 0000-0002-6416-0527

\section{The Religious Freedom in Crimea During the Russian Occupation}

\begin{abstract}
The article deals with the problem of religious freedom in Crimea after the occupation of the Peninsula by Russian military forces in February 2014 and the annexation of Crimea by the Russian Federation. The subject matter of the study is religious freedom in Crimea during the Russian occupation since 2014. The systematic and the structural approach allow the authors to see the entire picture of religious freedoms violation on the Peninsula. The study hypothesizes that with the occupation and annexation of Crimea, Russia brought the collapse of the religious pluralism and freedom that Ukrainians had experienced since 1991. In this paper, the authors cover a wide range of issues such as torture of religious activists, destruction and the illegal seizure of religious property, persecution of Ukrainians on political and religious grounds, deportation of Crimea's population to the mainland of Ukraine. The research establishes that the occupiers created unbearable conditions for religious freedom, the lives of many clergymen and believers appeared to be in great danger. Different religious communities, especially the representatives of the Orthodox Church of Ukraine (the OCU), Crimean Muslim Tatars, suffered significantly from applying Russia's severe criminal and administrative requirements. The analysis allows seeing the complete picture of religious discrimination of different denominations and cruel religious persecution in the annexed Crimea beginning from February 2014 till nowadays.
\end{abstract}

Key words: annexation, Crimea, human rights, persecution, religious freedom, international law

\section{Introduction}

The occupation of Crimea by the Russian Federation is one of the key points in the modern international relations system transformation. The fact of its transformation is not under discussion. However, af- 
ter February 2014, all international actors received an example of direct violation of the basic principles of the international law, such as respect for sovereignty and non-interference in the internal affairs of the state, respect for human rights (confirmed in the UN Charta) and the principle of the territorial integrity and inviolability of borders in Europe (Helsinki Act). Also, the Agreement was attacked about creating the CIS, which fixed the collapse of the Soviet Union and priority of the international law principles in the relations between the former Soviet republics.

Russian policy in the region of East Europe and post-Soviet republics of the Caucasus and Central Asia has different forms from the direct occupation of the territories, the support to the separatist movements, the financial instruments (investments, aid, joint ventures, etc.), and "humanitarian dimension" tools (question of the official language, minority rights, ethnical issue, etc.). The case of Ukraine is interesting for the investigation of the Russian instruments toward the neighbor states, their nomenclature, implementation, and effects.

\section{Literature Review and Research Background}

This article is a part of the investigation of the correlation between political and religious separatism in temporarily occupied territories of Ukraine. It means the authors tried to analyze all open sources in the field of Ukrainian religious politics, Russian politics and legislative on Crimea, international organizations reports (as interstate's, also NGO's, for example, the reports of the United States Commission on International Religious Freedom), numerous media information about the cases of violence and persecutions of different religious groups from the territories uncontrolled by Kyiv.

Due to the actuality of the problem, it is already clear that the problem lacks fundamental research such as monographs and articles. Although many Ukrainian scholars have already written a certain number of articles and books, for example, a comprehensive study of professor Oleksandr Zadorozhnii (2017) devoted Russian doctrine of international law after the annexation of Crimea, the article of the Permanent Representative of the President of Ukraine in the Autonomous Republic of Crimea - Dr. Anton Korynevych (2020) devoted to the Crimea after six years of Russian occupation, a grave violation of religious freedoms have not been studied thoroughly yet. 
It is necessary to underline the categories used by the authors and conferred in Ukrainian legislation. The term "temporary occupation" is used toward regions of Luhansk and Donetsk, but also Crimea. Nowadays, Crimea is not only occupied but also annexed by the Russian Federation. The instruments and tactics used in the Russian policy toward Ukraine during the conflict are very variable - from the propaganda negative image-making, psychological pressure to direct military intervention.

\section{Methods}

One of the basic methods applied by the authors is comparative analysis, which was used in two directions: the comparing situation with the religious freedom before and after Russian occupation and alignment of the cases of Crimea and so-called "peoples republics" in Luhansk and Donetsk. The method of the content analysis allowed to study a large volume of textual and visual data from different electronic and non-electronic resources.

The key method of this investigation is a case study because the authors analyze the problem of religious freedom in Crimea. This situation has very specific tools, cause the state which, against the rules of international law, occupied the territories of the neighboring state is a permanent member of the UN Security Council, has a nuclear weapon and military doctrine with the possibility of the preventive nuclear attack. Also, Russia changed its Constitution and declared Crimea as its administrative part. So, Russia has another point of view on the status of the Peninsula and its inhabitants. Another side of international law considers the annexation illegal, and all actions toward the local population, Ukrainian citizens, and their property, as well as Ukrainian property, are interpreted by international law.

\section{Case Study}

In this context, the question about the correlation between political and religious separatism in the situation in Crimea and the temporarily occupied territories of the Donetsk and Luhansk region is very actual and illustrative. Trying to analyze this problem in common, we need at the same time to underline differences in the situation of these two cases 
- Crimea and temporarily occupied territories of Donetsk and Luhansk region, which can have a principal influence on existing trends and future scenarios.

Russian troops occupied the Crimean Peninsula without insignias. In the end of February-March 2014, after that, the so-called "referendum" about the independence of Crimea from Ukraine was organized under Russian military presence, and after positive results, the self-proclaimed Crimean government signed an agreement about its incorporation into Russian Federation. So, Crimea was annexed by Russia.

In the case of the Donetsk and Luhansk regions, the situation escalated in another way. The so-called "people's republics" were proclaimed, financed, consulted, and organized by Russian secret services. Often the weapon and military servants are also sent by Russia, but formally these two constructs are independent.

In the first case, it means we have actions from the Russian government, and in the second, with the self-proclaimed separatist quasi-republics.

Before 2014, the situation with religious freedom in Ukraine could be characterized as pluralistic, heterogenous (many traditional and modern trends and communities), with the dominance of orthodox churches and secularism from the state. Religious freedom is also one of the main human rights declared in the Ukrainian Constitution. The affairs of 20132014 and the following ones also demonstrated a very flexible and soft attitude from the government toward the anti-Ukrainian activity of some religious communities.

For convenience in this thesis will be used such terms and abbreviations: the Orthodox Church of Ukraine (the OCU, was created after the Tomos receiving in 2018); the Russian Orthodox Church (the ROC); the temporarily occupied territories of Donetsk and Luhansk region (TOTDLR); the Ukrainian Orthodox Church of the Moscow Patriarchate (the UOC-MP); the Ukrainian Orthodox Church of the Kyiv Patriarchate (the UOC-KP, the OCU prior 2018); the United States Commission on International Religious Freedom (USCIRF). The acronyms "DNR" and "LNR" are used to make a point that Ukraine does not control these territories, so all restrictions and persecutions are from the side of the selfproclaimed authorities.

This article concentrates on the situation with religious freedom in Crimea as one of the basic human rights after the beginning of the Russian occupation in 2014 until December 2020, when this article was prepared. 
According to the United States Commission on International Religious Freedom (USCIRF) report in 2019, Russia is characterized as a "country of particular concern" and underlined that "Over time, the Russian government has come to favor the Moscow Patriarchate of the Russian Orthodox Church (MPROC) as the de facto state church (USCIRF, 2019). This favoritism has fostered a climate of hostility toward other forms of Christianity, increasingly perceived as foreign. This tendency has accelerated since President Vladimir Putin's reelection in 2012 and his strategic alliance with the Russian Orthodox Church."

The next thesis demonstrates the example of cooperation between the Russian military forces and some ROC priests during the Crimean occupation operation in February-March 2014. Some Russian military servants remember that in March 2014, they negotiated with Ukrainian commanders and soldiers through the aid of the priests from the ROC, e.g., Dymytry Vasilenkov (the vice-chairman of the Cooperation with the Army and law-enforcement agencies Department of the St.-Petersburg's Eparchy of the ROC). The maximum - task of such groups (consisting of the priest, "Kozaks," and armed men in the uniform without the grade insignia) was a peaceful disarming of the Ukrainian troops (Meduza, 2020).

In this context, the difference in tactics in Crimea and the so-called "LNR" and "DNR" should be underlined. In the first case, the priests of the ROC were used, not the Ukrainian Orthodox Church of the Moscow Patriarchate. On territories of self-proclaimed republics, the most active are the representatives of the UOC-MP, who are often the mediators with the separatist military groups, collaborate with them and the priests from the ROC. For example, in a few situations, the UOC-MP was the channel for the hostage rescue of Ukrainian soldiers. If in Crimea, the priority position is given to the orthodox churches of the ROC, in the "LNR" and "DNR," this role belongs to the UOC-MP. The Ukrainian secret service - SBU investigates the anti-Ukrainian activities of the representatives of the UOC-MP (Religious Information Service of Ukraine, 2018).

After the annexation of Crimea, some adaptations of the Russian legislation were made, especially for this republic. A certain problem was the requirement of occupation authorities for mandatory re-registration of all religious organizations in Crimea under Russian legislation before January 1, 2015. Federal Law No. 124-FZ as of 05.05 .2014 provides a slightly modified procedure of re-registration of legal entities in Crimea, containing many restrictive rules. 
According to the certificate of the Ministry of Justice (which is not a legislative act), to set up a local religious organization in Crimea, it is not required to provide documents confirming the existence of a religious group in a particular area for at least 15 years, as provided by federal law. However, the believers of Crimea are forced to comply with the other provisions of Federal Law No. 125-FZ "On Freedom of Conscience and Religious Associations" dated 26.09.1997, which significantly restricts their freedom of religion, unlike the laws of Ukraine.

As an example, religious organizations in Crimea have faced the following problems:

1. Re-registration of religious organizations under the legislation of the Russian Federation is possible only under two conditions: 1) entry into a centralized religious organization of a relevant religious confession; or 2) state religious examination in the manner prescribed by order No. 53 of the Ministry of Justice as of 18.02.2009 "On State Religious Expertise."

2. According to the requirements of the Ministry of Justice, in re-registration of centralized and local religious organizations, the original version of the current Statute of the religious organization registered under Ukrainian legislation shall be provided along with the document confirming its registration as a legal entity (for review, followed by a return to the applicant). Such a requirement is not provided by the legislation of the Russian federation that gives reason to see these hidden risks for believers and religious communities.

3. According to Federal Law No. 125-FZ, as of 09.26.1997, only Russian citizens may establish a religious organization with legal entity status. Therefore, this requirement makes the believing Crimean residents adopt Russian citizenship, and in case of failure, they are effectively being denied the right of association in a religious organization with the capacity of a legal person (Institute for Religious Freedom, 2015).

Attention should also be paid to the emergence of a threat to the preservation of property rights and access to places of worship and other buildings of religious communities in Crimea that have not been re-registered because 1) they are not part of any existing centralized religious organization; 2) they have not passed the state religion expertise; 3) non-compliance of the new version of their Statutes with the requirements of Russian legislation; 4) the believers' refusal to adopt Russian citizenship. 
Moreover, in contrast to Ukrainian law, which does not impose any conditions for religious communities without a legal entity status, Federal Law No. 125-FZ as of 09.26.1997 requires the founders to be subject to an entire procedure of establishing a religious community, even for the activities without a legal entity. This requirement correlates with the restriction of state registration of independent religious groups that have existed less than 15 years and prevents the activities of communities from being a part of a Russian religious center.

As a result, re-registration of religious organizations in Crimea means that they cannot continue to refer in their work on Ukrainian law, because under Federal Law No. 124-FZas of 05.05.2014, "their personal law is the right of the Russian Federation."

The UN Committee on the Elimination of Racial Discrimination is deeply concerned about the discrimination against ethnic and religious groups in Crimea. The Committee experts constantly urged the Government of the Russian Federation to provide the Office of the United Nations High Commissioner for Human Rights with full access to Crimea to monitor the situation. The Committee noted that the legislation and administrative measures that discriminate ethnic groups and indigenous peoples, including citizenship issues, availability of education in Ukrainian language, registration of religious communities, and activities of the Crimean Tatar self-government bodies, including Mejlis, are applied in the occupied Crimea.

According to the UN Committee, Russia has not provided information about the steps taken to investigate and prosecute those responsible for violating the rights of Crimean Tatars, including enforced disappearances, arbitrary detentions, and ill-treatment.

In 2014 the Crimean Tatars boycotted the referendum, so the widespread persecution of Crimean Tatar activists began almost immediately. Many people disappeared and later were confirmed to be killed. Both Crimean Tatar leaders Mustafa Dzhemilev and Mejlis Chairman Refat Chubarov had to leave and were refused permission to get back.

Human Rights Watch identifies 63 members of Crimean Tatar activists as having been charged by Russian authorities with supposed association with Hizb ut-Tahrir (Party of Liberation), a controversial pan-Islamist movement banned in Russia as a "terrorist" organization.

According to Memorial, in December, the North Caucasian Military District Court in Rostov-on-Don sentenced Crimean Tatar Remzi Memetov to 17 years in a penal colony. The court also sentenced Crimean Tatar 
Enver Mamutov, Rustem Abiltarov, and Zevri Abseitov to nine years each in a penal colony. The four were arrested in Crimea, Ukraine, in 2016, accused of belonging to Hizb ut-Tahrir and "preparing for the violent overthrow of the constitutional order," and transported to Russia. Human Rights lawyers noted that the case appeared to be retaliation against these men for their opposition to Russia's occupation of Crimea (United States Commission on International Religious Freedom, 2018).

During the last several years Russian FSB has conducted a series of raids on Tatar religious schools, placing numerous restrictions on the religious literature used in the mosques. More than 20,000 Crimean Tatars have left Crimea since 2014 for exile in Ukraine, Turkey, and other countries. Russian authorities routinely disrupt religious activities and institutions despite most opposition to Crimea's occupation being political and ethnic.

Under various reasons, such as fighting extremism, the occupation authorities of Crimea persecute people of the pro-Ukrainian religious organizations. The most egregious case occurred on March 15, 2014, when the Greek Catholic priest Mykola Kvych was illegally arrested by the Crimean authorities directly in the parish of the church of the Assumption in Sevastopol during communication with parishioners. It was accompanied by a deliberate desecration of the temple and shrines, further illegal actions toward the priest, violence, searches of private apartments, interrogation for 8 hours with elements of torture.

Mykola Kvych was forbidden to use the Ukrainian language during the interrogation. The priest faced the prospect of being sentenced to 15 years' imprisonment under the law on false extremism charges. For these reasons, on March 16, he was forced to leave Crimea.

Another problem for the Crimean believers is the Russian policy toward foreigners. The Federal Migration Service of Russia has not extended the residency term for foreign nationals working in the Crimean religious communities. For example, the Roman Catholic parish in Simferopol remained without its rector Fr Peter Rosohatsky, a citizen of Poland and has been working in Crimea for five years. The Greek Catholics faced similar problems. They complained of the forced rotation of priests due to the limitations in staying on the Peninsula for a period not exceeding three months.

In 2018, there were 23 prosecutions for "missionary activity" in Crimea, representing a twofold increase since 2016 (United States Commission on International Religious Freedom, 2019). Another example of 
the deep connection between religious and political issues in Crimea and TOTDLR is the necessity to register the OCU community and its political position toward annexation.

In a situation of occupation and military actions, the head of the UOC$\mathrm{KP} / \mathrm{OCU}$ decided to allow the priests to define themselves if they continue their activity on these territories. Prior to the conflict in 2014, there were 18 UOC-KP churches in the "LNR;" as of 2018, only two continued to operate.

After the Russian takeover of 2014, the Ukrainian Orthodox Church of the Kyiv Patriarchate (UOC-KP) refused to register, considering this a submission to an illegal occupation. Russian authorities responded by seizing church property and harassing clergy. During 2019 there was a struggle for the main cathedral in Simferopol, also through the attention of the United Nations, by at the December decision about the Orthodox Church of Ukraine (former UOC-KP) has no proprietary right on this building and territory was transferred to the Greek Catholic community (Religious Information Service of Ukraine, 2019). In such a way, Russian authorities try to create tensions in relations between two structures, which often have the same position toward the key questions about the situation in Crimea.

For more objectivity, we need to pay attention to alternative scenarios of the Russian governance in Crimea. For example, in 2019, 2 new mosques, 3 minarets, and 40 parcels were constructed for the Muslims as this religious community was divided and waiting for the end of the building of the Cathedral mosque in Simferopol in 2020 (Religious Information Service of Ukraine, 2020). At the same time, it was established and now works actively the pro-Russian Crimean Tatars information Channel "Melet." So, Russia built the structures of religious and ethnic identification for Crimean Tatar's alternative to the pro-Ukrainian institutions based in Kyiv through prosecutions against their leaders.

Another factor that can also change the religious situation in Crimea is the migration of the 500 thousand people from Russia and the militarization of the Peninsula. It could change not only religious but also ethnical correlations and could be challenged for the national identity of the Crimean Tatars (Ministry for the reintegration of the temporarily occupied territories of Ukraine, 2019).

On July 23, 2020, on the day of the 20th anniversary of his episcopal ordination, the Russian occupiers handed over a decree to the Archbishop of the Crimean Diocese of the OCU Kliment on the demolition of the 
church in Evpatoria. The US Ambassador to the OSCE criticized the decision of the occupying authorities of Crimea to dismantle the PCU temple. Also, a certain number of human rights organizations made a statement about the destruction of the Orthodox Church of Ukraine in Crimea. Metropolitan Epiphanius condemned the actions of the occupying Russian authorities in Crimea, and Metropolitan Alexander (Drabinko) called for an adequate response to "spiritual terrorism" in Crimea (Crimea Suspilne, 2020).

On August 4, 2020, the Supreme Court of the Russian Federation refused to reconsider the decision to evict the community of the OCU from the cathedral in occupied Simferopol.

Recently, the Office of the Prosecutor of the International Criminal Court has completed the study of the events in Ukraine, taken place since 2015. Soon, they will start investigating the violation of human rights in Donbas and the annexed Crimea (Prosecutor's General Office, 2020).

\section{Results}

Based on this material can be made such results:

- The case of Crimea is the interstate conflict between Russia and Ukraine, and both sides believe the Peninsula belongs to it. Ukraine appeal to international law in such main directions - attempts to recognize Russia as the aggressor; issues of property: human rights; terrorism financing. Russia ignores the international reaction and implements its policy of further incorporation of Crimea.

- Religious tolerance, which was the basis of Ukrainian politics in Crimea, has had different effects. This principle correlated with ethnic and religious heterogeneity of the Peninsula, but it also created a comfortable condition for the activity of Russian religious organizations, which supported the military invasion and occupation.

- During the occupation, Russian militants used the aid of Russian priests, not Ukrainian, with the pro-Russian position.

- After the beginning of the occupation, the religious factor was used by Russian authorities as an instrument of influence against the opposition (religious, political). Through the legislative mechanisms, sometimes adopted for the Crimea case, Ukrainian religious institutions, foreign churches, and Islamic centers of Crimean Tatars were displaced. 
- The property of some Ukrainian churches was nationalized and then became the property of Russian churches.

- Russia builds its own system of relations between different religious groups in Crimea based on loyalty to the state authority of the occupant. At the same time main the all-Russian religious structures are strengthened in the Peninsula, blurring the national and historical differences (trying to displace the problem of Crimean Tatars by a more common group of Muslims, for example).

- Nowadays, the international mechanisms are only one opportunity to declare, investigate, and make sanctions against Russian policy of the human rights violation in Crimea.

\section{Conclusion}

Analyzing the situation with religious freedom in Crimea, we need to remember that we observe incorporation in the Russian governance system based on the deep connection and collaboration between the state and religious communities. As in the other public spheres, there is no freedom or opposition to the official policy line. The prominent positions have the traditional communities such as the ROC. The RF constitution provides freedom of religion, equal rights irrespective of religious belief, and the right to worship and profess one's religion (Gosudarstvenaya Duma, 2020). The law states government officials may prohibit the activity of a religious association for violating public order or engaging in "extremist activity."

The law lists Christianity, Islam, Judaism, and Buddhism as the country's four "traditional" religions and recognizes the special role of the Russian Orthodox Church (Elektronuy fond pravovuh i normativnotehnicheskih dokymentov, 2021).

Unlike the authorities of the so-called "DNR" and "LNR, who use the Russian model of governance in the sphere of religious freedoms (legislative basis; main instruments; close cooperation with army, police and secret services and pressure under the opposition), but the dominant position still has the UOC-MP, in the Crimea, Russia provides its own institutional system without any possibility of future returning of the Peninsula to Ukraine. In both cases, the prominent role of the traditional religions and the especial position of Orthodox Christianity. It means discrimination and the survival of other religious groups. Ukraine must reflect all these factors on the local, regional and global levels. 
Thus, the occupation of Crimea, Donbas, has led to a significant complication of the situation with the religious freedoms in Ukraine. The terror of the occupiers forced believers of different religious communities to leave their homes. It is also clear that such violation of the humanitarian law can also be associated with the Ukrainian and the European orientation of these religious groups.

\section{Bibliography}

Crimea Suspilne (2020), Archbishop of the Orthodox Church of Ukraine Clement was handed a resolution on the demolition of the church in occupied Evpatoria, https://crimea.suspilne.media/en/news/622, 23.07.2020.

Elektronuy fond pravovuh i normativno-tehnicheskih dokymentov (2021), Federaluy zakon o svobode sovesti $i$ religioznyh obedineniy s izmeneniyami na 30 aprelya 2021 goda, https://docs.cntd.ru/document/9040821, 30.04.2021.

Gosudarstvenaya Duma Federalnogo Sobraniya Rossiyskoy Federatsii (2020), Noviy tekst Konstitutsii Rossii, http://duma.gov.ru/news/48953, 03.07.2020.

Institute for Religious Freedom (2015), Donbas and Crimea: new challenges for religious freedom in 2014, https://www.irs.in.ua/en/donbas-and-crimea-newchallenges-for-religious-freedom-in-2014, 03.02.2015.

Korynevych A. (2020), Crimea after six years of Russian occupation: fear, human rights abuses and absence of freedom, https://www.ukrinform.net/rubricsociety/3018470-crimea-after-six-years-of-russian-occupation-fear-humanrights-abuses-and-absence-of-freedom.html?fbclid=IwAR288XEdkYrIE5QJ Gp_syu9InVur1OGq5uOQF13d2B6_cVPhYA29ZY_s8v8, 04.05.2020.

Meduza (2020), Vezhlivye batushki. Kak svyasheniki RPC ychavstvovali v prisoedinenii Kryma, https://meduza.io/feature/2020/03/16/vezhlivye-batyushki?utm source $=$ email\&utm_medium $=$ vecherka\&utm_campaign $=2020-03-16$, 16.03.2020.

Ministry for reintegration of the temporarily occupied territories of Ukraine (2019), Speech by Oksana Koliada on the plenary session of the 74-th UN General Assembly, https://mtot.gov.ua/en/vistup-oksani-koljadi-na-plenarnomuzasidanni-genasambleii-oon, 16.12. 2019.

Prosecutor's General Office (2020), Mizhnarodnyu kriminalnyu syd zavershyv poperedni vyvchenya sytuatsii $v$ Ukraine shodo mizhnarodnogo zbroinogo konflikty na Donbasi ta v Krymy, https://www.gp.gov.ua/ua/news? $\mathrm{m}=$ publications\&_c $=$ view\&_t $=\mathrm{rec} \& \mathrm{id}=285393,11.12 .2020$.

Religious Information Service of Ukraine (2018), SBU rozslidye antyukrainsky diyalnist UPC (MP) na Donbasi, https://risu.ua/sbu-rozsliduye-antiukrajinskudiyalnist-predstavnikiv-upc-mp-na-donbasi_n90038, 30.03.2018.

Religious Information Service of Ukraine (2019), Na Genasamblei OON predstavleno problem z pravamy ludyuny $v$ aneksovanomy Krumy, https://risu.ua/na-ge- 
nasambleji-oon-predstavleno-problemi-z-pravami-lyudini-v-aneksovanomukrimu_n101709, 17.12.2019.

United States Commission on International Religious Freedom (2018), Russia 2018 International Religious Freedom Report, https://www.uscirf.gov/reportsbriefs/annual-report-chapters-and-summaries/russia-chapter-2018-annualreport.

United States Commission on International Religious Freedom (2019), USCIRF Annual Report, https://www.uscirf.gov/sites/default/files/2019USCIRFAnnualReport.pdf.

Zadorozhnii O. (2017), Russian doctrine of international law after the annexation of Crimea, Monograph, Kindle edition.

\section{Wolność religijna na Krymie w okresie rosyjskiej okupacji}

\section{Streszczenie}

Artykuł dotyczy wolności religijnej na Krymie po rozpoczęciu okupacji Półwyspu przez rosyjskie siły zbrojne w lutym 2014 roku oraz aneksji Krymu przez Federację Rosyjską. Przedmiotem badania jest wolność religijna na Krymie od tamtej pory. Wykorzystanie podejścia systematycznego i strukturalnego pozwala autorom przedstawić pełen obraz naruszeń wolności religijnej na Półwyspie. Na potrzeby studium założono, że wraz z zajęciem i aneksją Krymu Rosja doprowadziła do upadku pluralizmu i wolności religii, którymi Ukraińcy cieszyli się od 1991 roku. W przedstawionej pracy autorzy poruszają szereg zagadnień, np. torturowanie aktywistów religijnych, niszczenie lub nielegalne przejmowanie własności o charakterze religijnym, prześladowanie obywateli Ukrainy na tle politycznym i religijnym, czy deportowanie mieszkańców Krymu do innych obszarów Ukrainy. Na podstawie analizy ustalono, że okupanci stworzyli warunki uniemożliwiające korzystanie z wolności religijnej oraz stwarzające zagrożenie życia dla wiernych i duchownych. Różne wspólnoty religijne, szczególnie przedstawiciele Kościoła Prawosławnego Ukrainy i Tatarów krymskich, poważnie odczuły skutki działań Rosji, która wdrożyła przeciwko nim szereg procedur administracyjnych i kryminalnych. Analiza umożliwia dostrzeżenie pełnego obrazu dyskryminacji różnych wyznań na tle religijnym oraz okrutnych prześladowań na terenie Krymu od lutego 2014 roku do chwili obecnej.

Słowa kluczowe: aneksja, Krym, prawa człowieka, prześladowanie, wolność religijna, prawo międzynarodowe 
